\title{
Cushing syndrome induced by long-term use of corticosteroids in the management of atopic dermatitis
}

Zespół Cushinga wywołany długotrwałym stosowaniem kortykosteroidów w leczeniu atopowego zapalenia skóry

${ }^{1}$ Yasin Akkuş, ${ }^{2}$ Veysel N. Baş, ${ }^{1}$ Zülal Yılmaz

${ }^{1}$ General Pediatrics, Evliya Çelebi Eğitim Araştırma Hastanesi, Turkey

${ }^{2}$ Pediatric Endocrinologist, Evliya Çelebi Eğitim Araştırma Hastanesi, Turkey

\begin{abstract}
Corticosteroid-containing creams, pomades and ointments are frequently prescribed for the treatment of atopic dermatitis by allergologists and immunologists, dermatologists and many other physicians. This case is about a 1-month old infant who acquired iatrogenic Cushing syndrome after being applied diflucortolone valerate, a strong corticosteroid, ointment 3 to 4 times a day over the course of 4 months after being prescribed by a primary care physician.
\end{abstract}

Key words:

atopic dermatitis, Cushing syndrome, steroid creams. 


\section{Introduction}

Atopic dermatitis (AD [atopic eczema]) is an itchy, inflammatory and chronic recurrent skin disease that is common among 1-3 year-olds. Topical treatment of AD overall may enable strengthening of the barrier function, control of inflammation or treatment of staphylococcal colonization. Topical corticosteroids and especially calcineurin inhibitors are used to control inflammation among 2-4-year-old children. Drugs that contain strong corticosteroids may suppress the hypothalamopituitary adrenal axis, and cause undesirable systemic side effects such as Cushing syndrome especially among infants. In our case, high dosage of topical corticosteroid was applied over an extended period contrarily to the doctor's prescription, which resulted in Cushing syndrome.

\section{Case presentation}

A now 6-month-old male patient had redness, itching and crusting symptoms on both cheeks and inner elbows at the age of 1 month. He was prescribed diflucortolone valerate ointment once daily for a maximum of 7 days by a primary care physician. However, his family continued applying the treatment long after the symptoms resolved, 3-4 times per day for approximately 4 months. Afterwards, the infant was admitted to the pediatric endocrinology outpatient clinic of our hospital with redness, swelling on his face, weight gain, and a desire for excessive suction while being fed. Infant's medical history was inquired. He was born weighing 3270 grams at the $39^{\text {th }}$ week of gestation as a result of his 25-year-old mother's first pregnancy. Other than that his medical history and family history were unremarkable. Heart rate 118/min, arterial blood pressure $90 / 55 \mathrm{~mm} \mathrm{Hg}$ (89 p/94 p), body weight 7,500 grams $\left(25-50^{\text {th }}\right.$ percentile), height $65 \mathrm{~cm}\left(25-50^{\text {th }}\right.$ percentile), head circumference $44 \mathrm{~cm}$ (50-75 ${ }^{\text {th }}$ percentile) were measured during the physical examination. In addition, a more pronounced weight gain on the upper extremities and moon face appearance were observed during the physical examination.

The image of our patient when he applied to our pediatric endocrinology outpatient clinic at 6 months of age is given in Figure 1. His parents have been informed and they have consented to the usage of this image for this case report.

In laboratory examinations following values were acquired: serum glucose $109 \mathrm{mg} / \mathrm{dl}$ ( $\mathrm{N}$ : 70-105 mg/dl), total cholesterol $165 \mathrm{mg} / \mathrm{dl}$ (N: 45-180 mg/dl), LDL $66 \mathrm{mg} / \mathrm{dl}$ (N: 60-130 mg/dl), HDL $51 \mathrm{mg} / \mathrm{dl}$ (N: 5-34 mg/dl), triglyceride $242 \mathrm{mg} / \mathrm{dl}$ (N: 30$100 \mathrm{mg} / \mathrm{dl}), \mathrm{TSH} 1.91 \mathrm{mlU} / \mathrm{l}$ (N: 0.73-8.35 mlU/l), T4 $1.04 \mathrm{ng} / \mathrm{dl}$ (N: 0.9-2.3 ng/dl), RBC 4.08 million $/ \mu \mathrm{l}(\mathrm{N}: 3.1-4.5 \mathrm{million} / \mu \mathrm{l})$, WBC $13.310^{3} / \mu \mathrm{l}\left(\mathrm{N}: 6-17,510^{3} / \mu \mathrm{l}\right)$, Hb $12.4 \mathrm{~g} / \mathrm{dl}$ (N: 11.1$12.6 \mathrm{~g} / \mathrm{dl}$ ), HCT 37.1 (N: 31-36), PLT $79410^{3} \mathrm{ml}$ (N: 150-350 $10^{3} \mathrm{ml}$ ), morning serum cortisol $0.2 \mu \mathrm{g} / \mathrm{dl}(\mathrm{N}: 8-25 \mu \mathrm{g} / \mathrm{dl})$, adrenocorticotropin hormone $(\mathrm{ACTH}) 6.8 \mathrm{pg} / \mathrm{ml}(\mathrm{N}: 10-50 \mathrm{pg} / \mathrm{ml})$. In the low-dose $(1 \mathrm{mg})$ ACTH stimulation test, the peak cortisol level was $12.9 \mu \mathrm{g} / \mathrm{dlL}$ ( $\mathrm{N}$ : > $19.8 \mu \mathrm{g} / \mathrm{dl})$. latrogenic Cushing syndrome was considered due to the low cortisol response to
ACTH stimulation test. Ointment treatment was discontinued. $7 \mathrm{mg} / \mathrm{m}^{2} /$ day hydrocortisone treatment was started. The treatment was continued when the serum basal cortisol level became $0.3 \mu \mathrm{g} / \mathrm{dl}(\mathrm{N}: 8-25 \mu \mathrm{g} / \mathrm{dl})$ at $3^{\text {rd }}$ month of the follow-up. The peak cortisol response to low-dose ACTH test at $6^{\text {th }}$ month of treatment was found to be sufficient with $22.9 \mu \mathrm{g} / \mathrm{dl}$ and then the hydrocortisone initiated at physiological dose was discontinued. Two months after discontinuation of hydrocortisone, the patient's physical examination revealed: $96 / \mathrm{min}$ pulse rate, $85 / 50 \mathrm{~mm} \mathrm{Hg}$ arterial blood pressure, $9.3 \mathrm{~kg}$ body weight (25-50 ${ }^{\text {th }}$ percentile), $72 \mathrm{~cm}$ height (10-25 ${ }^{\text {th }}$ percentile), $46.5 \mathrm{~cm}$ head circumference (25-50 $0^{\text {th }}$ percentile). Cushingoid appearance was significantly decreased (Fig. 2).

\section{Discussion}

Atopic dermatitis is a chronic, itchy and inflammatory dermatosis that affects $20-25 \%$ of children [1-3]. Atopic dermatitis most often begins in infancy between 3 and 6 months. While the majority of patients recover during adolescence, on average $25 \%$ of patients receiving diagnosis do not recover. The pathogenesis of the disease leads to a decrease in skin hydra-

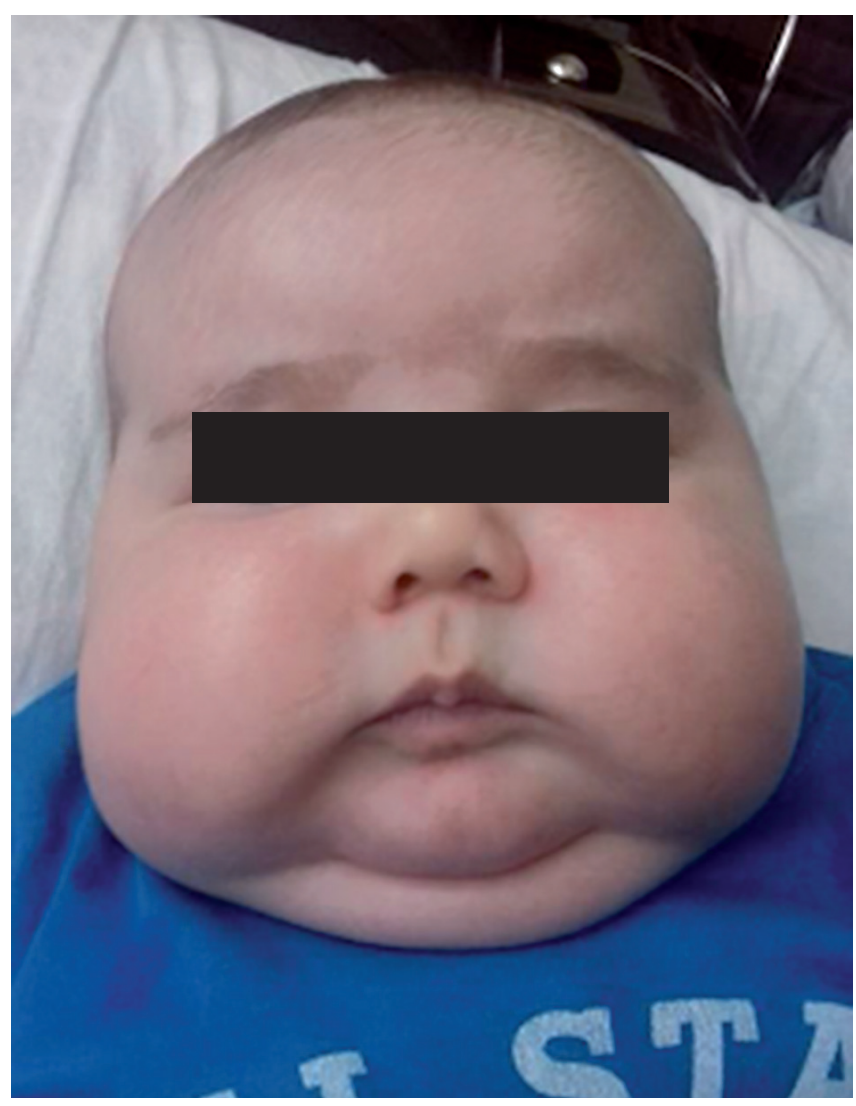

Figure 1. latrogenic Cushing syndrome 


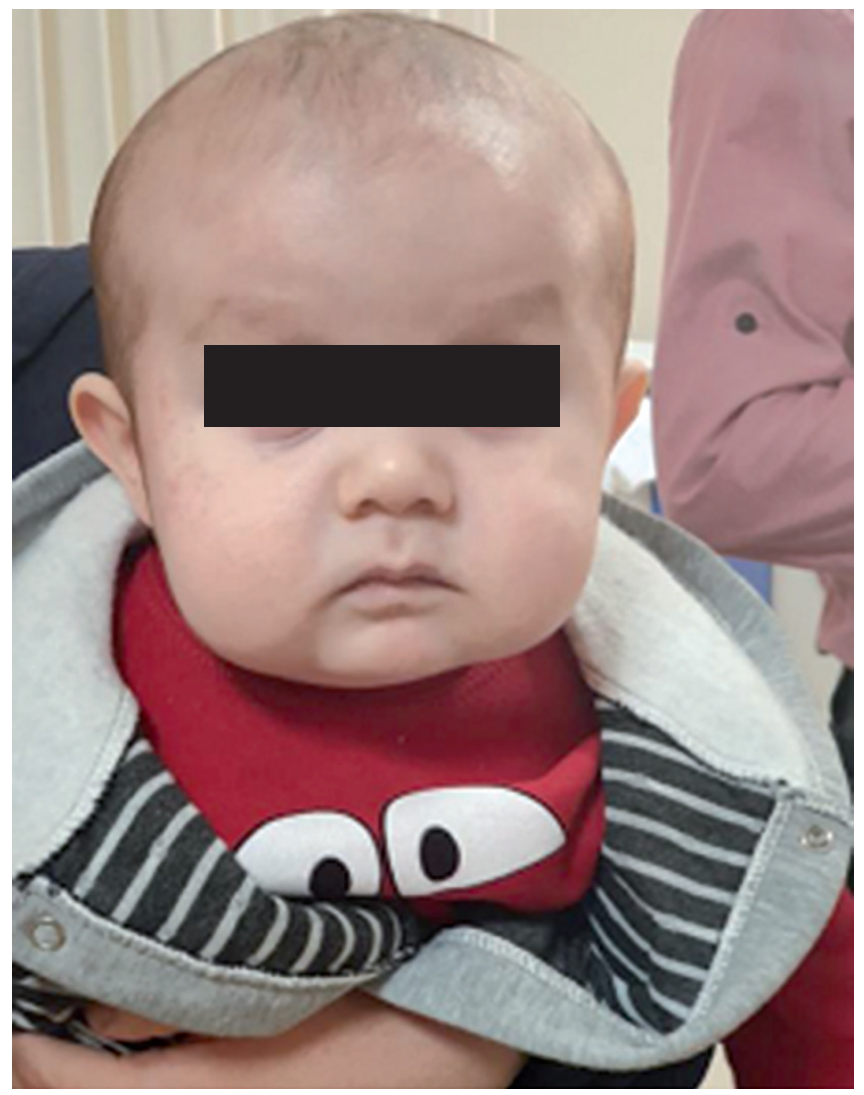

Figure 2. Appearance of patient after treatment

tion, an increase in water loss, and a deterioration of skin structure and function due to changes in ceramide and lipid content. On the other hand, inflammatory findings with proinflammatory cytokines are observed in the lesion site with an increase in predominantly Th2 and Th17, Th22. Therefore, in infants and nurslings children, firstly vesicles are seen on the cheeks, scalp and extensor faces of the extremities and in severe cases serous exudates and crusts may occur. In the chronic period, squamous, pruritic, erythematous and crusted lesions are seen. The trunk region may be involved, although rarely. Despite that diaper region is almost never involved.

Corticosteroids are used to control inflammation and calcineurin inhibitors are used especially for patients above 2 years of age. Topical corticosteroids are used in the treatment of exacerbation episodes of $\mathrm{AD}$, as well as for long-term remission. Since infants and nurslings children are under greater risk in terms of local and systemic side effects than adults, high po- tency steroids should not be used in patients in this age group $[3,6]$. Although topical corticosteroids are recommended twice daily for the treatment of acute exacerbation of atopic dermatitis, some studies have demonstrated similar results in the administration of corticosteroids once or twice a day. The application dose is determined by the size of fingertip. One fingertip of the corticosteroid is sufficient to cover an area corresponding to 2 adult palms. This amount corresponds to approximately $0.5 \mathrm{mg}$ [6]. After clinical improvement is achieved; replacement of the treatment with a lower potency drug, intermittent use ( 2 days per week) or combination therapies with other nonsteroidal drugs may be useful to minimize the side effects of local topical corticosteroid treatment [7]. Side effects that may occur due to topical steroids include; local side effects such as atrophy, acneiform rashes, perioral dermatitis, telangiectasia, striae formation, hypopigmentation, development of secondary skin infections and delay in wound healing, as well as systemic effects such as Cushing syndrome, cataract or glaucoma, femoral head necrosis, and suppression of the hypothalamic pituitary axis. Although the most common cause of Cushing syndrome is oral glucocorticoid therapy, Cushing syndrome has been reported after long-term use of strong and very strong topical steroids in the literature, as well as in our case. In addition, there are many cases of hypercortisolism after inhalation treatments, ocular and nasal drops [8,9].

Moon face appearance, buffalo hump, obesity in the trunk, hirsutism, purple striae, acne, growth deceleration and hypertension are the findings that guide physicians towards Cushing syndrome [10] diagnosis. In our case, moon face, more pronounced weight gain in upper extremities are typical findings (Fig. 1). Diflucortolone valerate is one of the most potent topical steroids and is classified as a potent effective glucocorticoid. In our case, diflucortolone valerate was administered at high doses for 4 months. As a result, suppressed serum cortisol levels clinically led to Cushing syndrome. An adequate response could not be obtained to the low dose ACTH stimulation test Which was applied to the patient. Adrenal insufficiency due to suppression of the hypothalamo-pituitary-adrenal (HPA) axis secondary to topical steroid treatment was considered and low-dose oral hydrocortisone treatment was applied for approximately 6 months. When the stimulated serum cortisol level of patient reached normal levels, the patient's hydrocortisone treatment was discontinued.

In conclusion, our case report aims to encourage physicians to prefer weak-acting topical corticosteroids by taking into consideration the side effects of the strong-acting alternatives. Moreover, our case would like to emphasize the importance of informing the families about corticosteroid use and possible side effects of misusage in a detailed, clear, comprehensible way. 


\section{References}

1. Weidinger S, Novak N. Atopic dermatitis. Lancet 2016; 387: 11091122. doi: 10.1016/S0140-6736(15)00149-X

2. Eichenfield LF, Tom WL, Chamlin SL, et al. Guidelines of care for the management of atopic dermatitis: section 1. Diagnosis and assessment of atopic dermatitis. J Am Acad Dermatol 2014; 70 : 338-351. doi: 10.1016/j.jaad.2013.10.010

3. Katayama I, Kohno Y, Akiyama K, et al. Japanese Guideline for Atopic Dermatitis 2014. Allergol Int 2014; 63: 377-398. doi: 10.2332/allergolint.14-RAI-0769

4. Ertam I, Su O, Alper S, et al. Türkiye atopik dermatit tanı ve tedavi kIlavuzu-2018. Turkderm-Turk Arch Dermatol Venereology 2018; 52 : 6-23.

5. Suárez-Fariñas M, Tintle SJ, Shemer A, et al. Nonlesional atopic dermatitis skin is characterized by broad terminal differentiation defects and variable immune abnormalities. J Allergy Clin Immunol 2011; 127: 954-964. doi: 10.1016/j.jaci.2010.12.1124

6. Eichenfield LF, Tom WL, Berger TG, et al. Guidelines of care for the management of atopic dermatitis: section 2. Management and treatment of atopic dermatitis with topical therapies. J Am Acad Dermatol 2014; 71: 116-132. doi: 10.1016/j.jaad.2014.03.023

7. Chong M, Fonacier L. Treatment of Eczema: Corticosteroids and Beyond. Clin Rev Allergy Immunol 2016; 51: 249-262. doi: 10.1007/ s12016-015-8486-7

8. Baş VN, Çetinkaya S, et al. latrogenic Cushing Syndrome Owing to Topical Steroids. J Child 2010; 10: 152-155.

9. Baş VN, Çetinkaya $S$, et al. latrogenic Cushing syndrome due to nasal steroid drops. Eur J Pediatr 2012; 171: 735-736. doi: 10.1007/ s00431-011-1645-9

10. Akan T. Topikal kortikosteroidlerin kullanımı. Katkı Pediatri Dergisi 2000; 21: 599-604. 